\title{
QUALITY OF LIFE FROM THE PERSPECTIVE OF REVASCULARIZED PATIENTS DURING REHABILITATION: AN ETHNOGRAPHIC STUDY ${ }^{1}$
}

\author{
Vanessa da Silva Carvalho Vila ${ }^{2}$
} Lídia Aparecida Rossi ${ }^{3}$

Vila VSC, Rossi LA. Quality of life from the perspective of revascularized patients during rehabilitation: an ethnographic study. Rev Latino-am Enfermagem 2008 janeiro-fevereiro; 16(1):7-14.

This ethnographic study aimed to understand the meaning of quality of life from the perspective of people with coronary disease submitted to myocardial revascularization surgery. Direct observations and semi-structured interviews were used for data collection. Data were analyzed through careful reading, identification of units of meaning, thematic groups and themes, and interpreted according to interpretative anthropology and the Centre for Health Promotion conceptual model of quality of life. The identified theme, quality of life - being happy as possible, is based on being healthy, having a job and a harmonious family. These were considered dimensions for a "tranquil and happy" life. The meaning of quality of life is complex, subject to new significations throughout life, and related to the socioeconomic and cultural context, including, in the case, the experience of the health-disease process.

DESCRIPTORS: quality of life; myocardial revascularization; anthropology, cultural; health

\section{LA CALIDAD DE VIDA BAJO LA PERSPECTIVA DE CLIENTES REVASCULARIZADOS EN REHABILITACIÓN: UN ESTUDIO ETNOGRÁFICO}

Este estudio etnográfico tuvo como objetivo comprender el significado de calidad de vida en la perspectiva de personas que tuvieron una coronariopatía y pasaron por cirugía de revascularización del miocardio. Los datos fueron recolectados por medio de observaciones directas y entrevistas semiestructuradas y evaluados a partir de una lectura cuidadosa, de la identificación de unidades de significados de núcleos temáticos y temas. Fueron interpretados de acuerdo con la antropología interpretativa y el modelo conceptual de calidad de vida del Center for Health Promotion. El tema identificado, calidad de vida - ser feliz en la medida de lo posible, está fundamentado en tener salud, tener trabajo y tener armonía familiar. Esas fueron consideradas dimensiones para una vida "tranquila y feliz". El significado de calidad de vida es complejo, está sujeto a nuevas evaluaciones de significado a lo largo de la vida, y relacionado al contexto socioeconómico y cultural, incluyéndose, en ese caso, la experiencia del proceso salud y enfermedad.

DESCRIPTORES: calidad de vida; revascularización del miocardio; antropología cultural; salud

\section{A QUALIDADE DE VIDA NA PERSPECTIVA DE CLIENTES REVASCULARIZADOS EM REABILITAÇÃO: ESTUDO ETNOGRÁFICO}

Este estudo etnográfico teve como objetivo compreender o significado de qualidade de vida na perspectiva de pessoas que vivenciaram a coronariopatia e a cirurgia de revascularização do miocárdio. Os dados foram coletados por meio de observações diretas e entrevistas semi-estruturadas e analisados a partir da leitura cuidadosa, identificação de unidades de significados, núcleos temáticos e temas. Foram interpretados de acordo com a antropologia interpretativa e o Modelo Conceitual de Qualidade de Vida do Centre for Health Promotion. O tema identificado, qualidade de vida - ser feliz à medida do possível, está fundamentado em ter saúde, ter trabalho e ter harmonia familiar. Essas foram consideradas dimensões para uma vida "tranqüila e feliz". O significado de qualidade de vida é complexo, está sujeito a (re)significações ao longo da vida, e relacionado ao contexto socioeconômico e cultural, incluindo-se, nesse caso, a experiência do processo saúde-doença.

DESCRITORES: qualidade de vida; revascularização miocárdica; antropologia cultural; saúde

${ }^{1}$ Paper extracted from Doctoral Dissertation; ${ }^{2}$ RN, Doctoral student, Interunit Nursing Doctoral Program at the University of São Paulo at Ribeirão Preto College of Nursing, Assistant Professor I at Goiás Catholic University, Brazil, e-mail vscvila@uol.com.br; ${ }^{3}$ Associate Professor, University of São Paulo at Ribeirão Preto College of Nursin,WHO Collaborating Centre for Nursing Research Development, Brazil, e-mail: rizzardo@eerp.usp.br 


\section{INTRODUCTION}

Despite the downward tendency in death rates, cardiovascular diseases are still the main cause of death in developed countries or in developing nations like Brazil. Health statistics appoint coronary artery disease (CAD) as responsible for one third of deaths in Brazil and early death rates related to this disease are higher when compared to other countries $^{(1)}$.

Therapeutic and technological advances in cardiology have permitted the survival of people affected by coronary disease. Coronary artery bypass grafting, which is the most used surgical procedure for CAD, has been carried out in ideal conditions, seeking to guarantee the relief of coronary insufficiency symptoms, improved cardiac functioning, prevention of myocardial infarction and patients' physical, mental and social recovery, aimed at improving their quality of life ${ }^{(2-3)}$.

The study of quality of life is important for the clinical decision making process and for the determination of therapeutic benefits, and also as a means to assess the patient's survival, in this case after coronary artery bypass grafting, which requires not only adequate medication use, but also changes in life habits ${ }^{(2,4)}$.

Different researchers have looked at quality of life related to coronary artery disease and the impact of its treatment on the individual's life today ${ }^{(2-}$ 6). These studies are considered important, because, besides evaluating the therapeutic results, they generate new hypotheses and reflections that permit a broader focus in studies on quality of life, seeking methodological options in terms of the discussion of theoretical and conceptual aspects involved in the evaluation of this phenomenon.

It is important to know the meanings of quality of life for these people, having in mind that it is an abstract concept, which has specific meanings produced by groups, configured as sociocultural constructions which people interpret subjectively ${ }^{(7)}$.

This study aimed to understand the meaning of quality of life from the perspective of people (persons submitted to coronary artery bypass grafting and their relatives) who experienced the coronary artery bypass grafting between six months and two years after the surgery.

\section{THEORETICAL-METHODOLOGICAL REFERENCE FRAMEWORK}

The theoretical foundation of this ethnographical study is based on concepts of Interpretative Anthropology and the Conceptual Model of Quality of Life of the Centre for Health Promotion $(\mathrm{CHP})$, from the University of Toronto ${ }^{(8-9)}$.

The interpretative chain of anthropology attempts to understand the meanings expressed in the experience world and its basic premises are based on hermeneutical dialectic philosophy. In this paradigm, the researcher and the participants are interlocutors involved in a dialogical relation. Thus, a "fusion of horizons" exists, which demands inclusion, penetration and confrontation among the cultural horizons, as well as the researcher's continuous confrontation with his/her theoretical horizon and permanent self-reflection and criticism ${ }^{(10)}$.

Interpretative studies try to articulate culture, health and disease, understanding culture as a web of interlaced meanings woven by man, which may be influenced by historical, economic, social, political and geographical factors. In this respect, the understanding of events related to life, such as the disease experience and the meaning of quality of life, becomes possible when they are considered the cultural elements that permeate the interrelation between individuals and the context of their social and symbolic reality ${ }^{(11-12)}$.

The social reality can be figured out as a system of symbolic meanings and rules that guide behavior, perception of the world, communication with people and the understanding of the internal and external world that is part of the socialization process. Through language and the systems of intersubjetively interlaced meanings, the so-called symbolic reality appears. This reality dimension is understood as the bridge that links the sociocultural to the physical (material aspects) and biological world (physical body) and to the psychological (mind aspects) reality, which permanently contribute to the construction of the personal identity, according to social and cultural rules experienced in the family and community context ${ }^{(12)}$.

Therefore, the meaning of disease experience and quality of life is built, unbuilt and rebuilt, through the experiences lived by the people and the explanatory models, considered notions on the illness and treatment process which are used by everybody involved in the clinical process. This way, the study of 
the explanatory models, the subjects and their relatives, reveals something about how they see, care for and treat the disease and how they choose or evaluate specific treatments. These concepts also guide the comprehension of the meaning of quality of life, considering the important and possible dimensions for happiness, satisfaction and well being in the context of the health and disease process ${ }^{(12)}$.

This perspective can help professionals to transcend the biomedical conceptual model of the health and disease process, to incorporate critical, reflexive thoughts and to the interpretative dimension of the meaning of quality of life broader and more dynamic. Thus, it can help professionals to consider this concept as a result and a process built in the perspective of people who experienced a coronary disease and coronary artery bypass grafting.

Among the conceptual models of quality of life, the Quality of Life Model of the Centre for Health Promotion was adopted, as it uses the holistic view and considers that the concept of quality of life is built from a continuous interrelation between the individual and the environment / reality ${ }^{(8-9)}$. In this model, quality of life is recognized as a dynamic phenomenon that results from the balance between limitations and opportunities, resulting from the possibilities in people's life. The possibilities result from the choices and opportunities that influence the level of personal control over the events in the individual's life. Therefore, quality of life is defined as "the level at which the person enjoys the use of important possibilities in his/her life" and its meaning is influenced by the importance and satisfaction level, defined on the basis of the interrelation among the dimensions of "being", "belonging" and "becoming", and the social and symbolic reality experienced by the individual ${ }^{(8-9)}$.

"Being" includes three dimensions of life related to human existence. The physical being focuses on the body and on physical aspects of health (good shape, agility and mobility, nutrition, hygiene, physical appearance). The psychological being refers to the person's thoughts, feelings and mental health. This dimension comprises self-esteem, self-image, self-control and ability to cope. The spiritual being refers to people's beliefs, values and life standards. It comprises the meaning of what is right or wrong, the meaning of life, the feeling of peace and the celebration of special events like birthdays and commemorative dates ${ }^{(8-9)}$. "Belonging" consists of the person's adjustments to his/her physical (home, work, school, neighborhood and community), social (social interactions, interpersonal relationship - friends, family, co-workers, neighbors) and community (access to resources derived from the community, social and health services, education, public events) environment ${ }^{(8-9)}$. "Becoming" corresponds to the person's actions to reach his/her goals, objectives, aspirations and hopes. These actions may be daily activities (involvement with work, voluntary activities and self-care); leisure (fun, relaxation, hobbies, social interaction and travel) or growth activities (learning, personal change and development, new challenges and adaptation to the changes in life $)^{(8-9)}$.

This study was based on the premise that: quality of life is a multidimensional construct; every individual is naturally biopsychosocial (physical, psychological and social aspects) and in continuous interaction with his/her reality; as it emerges from the complex interaction of the individual with the environment, a holistic reference framework needs to be adopted to understand quality of life; the components of quality of life are the same for people with or without inabilities; an inability or disadvantage condition alone does not necessarily lead to the increase or decrease of the person's quality of life; the basic components of quality of life are common things for all people and constitute the human condition. Although the basic components of quality of life are the same for all people, the meaning related to quality will vary to different extents from one person to another. That happens because individuals attribute different importance levels to the basic components of quality of life and have different opportunities or restrictions in the context of their lives ${ }^{(8)}$.

\section{Methodology}

The fieldwork was carried out between November 2003 and April 2005, initiated after the approval by the Research Ethics Committee at the hospital where the social group under analysis was selected from.

The selected social group consisted of people (individuals and relatives)* who experienced coronary artery bypass grafting at a large philanthropic hospital located in Goiânia, Goiás. These people agreed to

* Subject refers to the persons submitted to coronary artery bypass grafting who participated in this study. The participants will be identified through the subject's number S1), the letter corresponding to the gender (M-male and F-female) and the age. Relatives will be identified by their degree of kinship and age. 
participate in the study, after reading and signing a free and informed consent form.

Eleven people participated in the study, seven men and four women, between 53 and 74 years old, most of them married and with children. Religions included Catholic, evangelic and spiritualist, although Catholicism predominated. The education level is low and the same is true for the salaries received, except for one of the participants (S10, M, 58)*. From the 11 participants, seven are retired, six of whom due to age or other associated chronic diseases (stroke, diabetes, chronic renal insufficiency). Only one person (S10) was retired for disability due to the surgery. The other individual (retired before the cardiac problem) had a low income and worked to complement the monthly income and help in domestic expenses. These activities were, in general, informal activities like selling pineapples, clothes, ice cream, embroidery, sewing and planting corn to sell in the street market, among others.

Considering that the experience of this process involves the family core, family members (wives, husbands, sons, daughters, grandchildren and friends) who were present during visiting hours and demonstrated interest and availability were invited to take part in the study, so that ten relatives, nine women and a man participated. Ages varied from 26 to 62 years and education levels from elementary to incomplete higher education, which could be considered a little higher among relatives. However, monthly income remained low when considering the family context as a whole (three to seven people on the average).

The family members' participation contributed to contemplate as reliably as possible, the events, striking situations and the reality of everyday life in the description of the disease experience. The dialog between family members and subjects was favored, revealing the contradictions and similar and different standards to interpret reality. The family members who took part were those the subjects identified as "best friend", "who takes care of the family" and "whom I trust".

The data were collected through direct observations and semi-structured interviews held at home in several meetings, until the participants' social reality could be described. The following guiding questions were considered in the interviews: What aspects do you consider a priority and important in your life? What is the meaning of quality of life for you?

For each research subject, a "narrative dossier" was structured, consisting of identification data, field notes, fully transcribed narratives and data obtained from patient files. The meetings were transcribed as soon as the visit was over. The obtained information was registered in a way that did not permit the participants' identification.

Data analysis was considered as the act of interpreting, through reading, organization, search for common and divergent standards narrated by the research individuals, observed during the field work and contextualized in the researcher's theoretical reference framework. In this sense, data analysis happened during the whole field work, from the selection of the possible participants until the composition of the ethnographical text, built from the data description and the interpretation of its meanings within the research context. The construction of the ethnographical text was based on a set of data collected and addressed with the transcribed text, the observations made, and the interpretations built by the study participants as well as the researcher (intersubjetively).

\section{THE MEANING OF QUALITY OF LIFE - BEING AS HAPPY AS POSSIBLE}

From the comprehension of the meanings attributed to a good quality of life, the narratives converge to the perception of quality of life related to well being, happiness, satisfaction, possibilities in life, with the following central themes: being healthy, having a job and getting along with the family. These were considered important dimensions for a "calm and happy" life. In the central theme of being healthy, statements on aspects related to physical (eating well, sleeping, not feeling pain and weakness, taking medicine), emotional (dating, dancing, having peace and tranquility of mind) and spiritual health (having faith and believing in God) were included. The individuals mentioned that health is the "most important" indicator and should be put first, because being healthy is an essential factor so that they can work, make money and take care of their family. They define health as:

* Subject refers to the persons submitted to coronary artery bypass grafting who participated in this study. The participants will be identified through the subject's number S1), the letter corresponding to the gender (M-male and F-female) and the age. Relatives will be identified by their degree of kinship and age. 
[...] being healthy is feeling nothing wrong! Being calm with a good life [work and money], feeling no pain! (S3, M, 56).

[...] Being healthy is eating well, feeding well, sleeping well, and praying for God to give me strength. [...] Including dating! (S9, M, 62).

[...] Being healthy is having faith in God! (S4, F, 53).

Health is associated to the dimension of "being", defined by the CHP's Conceptual Model of Quality of Life as the dimension that involves physical aspects related to health (hygiene, eating well, not feeling pain and weakness, taking medicine), psychological aspects (mental health, self-esteem, self-control, ability to face) and spiritual aspects (having faith in God, feeling peace, tranquil conscience, harmony and having hope $)^{(8-9)}$. The meaning of "being" healthy converges to normative and positive aspects that involve both subjective and objective factors related to who the person is.

The notion of "being" healthy is built based on society's social and political processes, in a game of internal powers. Thus, health should be considered inside a complex organization of the life processes, because being healthy would always be similar to owning less state of normality and having more dynamic experiences in one's existence, which oscillate between disorder (illness) and order (health) and range go from suffering to pleasure, in the capacity of maintaining an identity in personal growth $^{(13-14)}$. The disorders would thus be a latent space for the development of both positive and negative powers, when the pathology would be seen as a privileged moment of life to reach new ways of growth and transcendence of personal limitations. In this sense, one can feel healthy despite experiencing physical or mental problems, as described in the following statements:

[...] I am sick but I feel healthy! I am full of health problems, but I do not give in, I have faith in God and peace in my family, then I am healthy, because it is not only the physical it is the mind as well! (S1, F, 74).

[...] health is the best thing that exists, it is wealth! It is as if I had a little bag of gold and said you are going to spend only one a day! Then you spend more, and more! And then health is over, what are you going to do? You are going to fight in another way. Health is over, it is like I am living, it is medication, it is everything! I still have an advantage because it does not cause me problems for sleeping, eating, it does not cause me any problem! I do not feel anything, for me that is a great advantage! But I am going to do what I cannot, I cannot travel as I used to, I like doing sales, provided with health that is everything, when you do not have health it is difficult. I think being healthy is the best wealth a person has. If you are healthy you can work, you can eat everything! (S2, M, 64)

Health constitutes, then, a dynamic state that can depend on many social, economic, political, historical, cultural, genetic, mental and lifestyle factors. It does not involve complete well being, total normality, absence of abnormality, since this conception is distant from the concrete reality. Health involves moderate suffering, with predominance of feelings of well being; it is a desired ideal, but also a concrete reality ${ }^{(13-14)}$. It means one can get sick and get out of the pathological state. The absence of illness does not necessarily mean health. Therefore, if an ill individual resists in affirming he is well, he should be considered healthy ${ }^{(13-14)}$.

In this study, health appears as something to be conquered. People use both objective and subjective aspects to define the health state. Therefore, they use the "compensatory logic" when mentioning that they feel healthy. They do not have physical health, but they have faith, tranquility and believe in God. In this sense, to establish the health definition, people elaborate a list that varies from the simple absence of disease to the conception of balance, understood as the possibility to dominate pressures and problems of social life in the best possible way.

Being healthy was associated to having faith and a religion, the need to believe in something transcendental, in something supernatural that is inherent to the human being. The spiritual dimension, in this study, was considered of extreme use and an essential condition to life when the individuals felt unable, insecure and afraid of death. This dimension is related to the need to find meaning, purpose and fulfillment in life, the need for hope/desire to live, the need to have faith in God and in the family, as strategies to cope with the illness experience ${ }^{(15-16)}$.

The religious experience and expression, present in different cultures, represent an important source of support and comfort for many people when experiencing pain and suffering, favoring serenity to support the adversities of a disease ${ }^{(16)}$. The faith and trust in one God can mean the hope and certainty so desired and so distant in the situation of fragility and impotence in the illness experience.

Religiosity and spirituality have always been considered important allies of people who suffer and/ or are ill. For many people, religion and personal and 
spiritual beliefs are a source of comfort, well being, safety, sense of belonging, ideal and strength, which was observed in the study participants' narratives ${ }^{(15-}$ 16). Spirituality is considered the dimension of the essential and complex life, experienced in a good and intense way, but still little discussed in literature on this them. Spirituality covers those aspects in life associated to moral and ethical principles, celebrations of important events in life (birthday, Christmas...) and transcendent experiences. Feelings of peace, comfort, harmony and hope in the future that, generally, follow the positive experience of the spirituality either can or cannot be associated to the formal practice of a religion or religious tradition. Spirituality is strongly influenced by the society the individual lives in ${ }^{(9)}$.

The fact of having a job was considered an important dimension to promote material well being, to obtain possessions and to have money. Through their work, people earn money, which is recognized as the means to promote personal development for self-sufficiency (independence/autonomy), physical, mental and social well being. Having a job appears associated to the dimension of "becoming", comprehended as the activities people performs to reach their objectives and expectations ${ }^{(8-9)}$. In the conceptual model used in this study, work represents a practical action the person practices regularly, and it includes formal and informal paid work, as well as, the activities of the daily life (housekeeping, taking care of children, pets $)^{(8-9)}$. Work has a direct and positive repercussion on health, because it entails the opportunity of having money to take care of food, medication and to have a productive and independent life, contributing to improved self-esteem and increased power to make decisions about one's choices.

As previously discussed, in terms of satisfaction with work, the participants, including those who had already retired, mentioned that they experienced a limitation to return to their labor activities after the surgery, which had a repercussion in terms of low self-esteem and perception of financial dependence. Socially, work has a very important moral role and not working means exposure to discrimination; therefore, restriction to work becomes a moral burden and a sub-human condition ${ }^{(17)}$.

Work is recognized as a fundamental standard and a requirement society imposes on the body, mind and behavior. It represents the individual's link to the human community and one of the most active forms for people to live in the family group, without which they lose balance and lose touch. In a capitalist society, the impossibility of working, supporting oneself and one's own needs and surviving, leads the person to the feeling of delinquency, of being out of the productive system, a dependent person and without autonomy. It is through professional activity, through work that human beings achieve dreams, projects, expressing and identifying themselves. Provided with the disease and the possibility of not returning to work, the human being feels stigmatized, a body that no longer answers to the productive requirements of a consumption society ${ }^{(16)}$.

The central theme of having harmony in the family grouped statements in which the participants mentioned that the family is one of the important aspects for quality of life. The family center is the social environment in which welcoming, interaction and social support happen, and was considered the main center of both financial and emotional support for the individual. In this sense, having a family represents the belonging described in the CHP's Conceptual Model of Quality of Life as the congruity level between the people and the environment they are related to. This dimension involves belonging in terms of aspects related to housing, privacy, family environment (welcoming) and social aspects related to interpersonal relationship and feeling in touch with other significant people ${ }^{(8-9)}$.

The family is an important space for the individual's development. It is the primary social group the individual belongs to, and it influences the learning of social roles and the formation of the social and individual identity, through the intersubjetive sharing of rules of behavior, beliefs and moral values ${ }^{(18)}$.

In this study, it was observed that the family was an important source of emotional and social support and contributed to face problems related to the health and disease process as well as other social problems involving these people's daily life.

Besides the family support, the subjects mentioned that putting their lives in the hands of God, believing that God gives them strength and that God knows what to do, not complaining because it was God's will and having faith brings comfort and hope. These statements permeated the research subjects' narratives, both in the reports about the disease experience and about the meaning of quality of life.

Although the participants mentioned that they are not satisfied with all of these dimensions, they 
said they are happy, because they consider that they cannot "complain of what they have despite of everything". The conformation and resignation to the experienced social reality are characteristic of the study group.

They considered that they have quality of life (peace and harmony in the family, having faith in God, a house and food), in spite of not being healthy (from the physical point of view) and they face socioeconomic problems due to the limitations imposed by the health conditions (unemployment, retirement for disability, dependence on family care), as previously discussed. This way, quality of life can be defined as a subjective well being that reflects the differences, the gaps between the expectations of a person and his/her actual experience ${ }^{(5,8-9)}$, as shown in the following statements:

[...] because I do not have health, but God finds a way! I cannot complain because thanks to God we are still walking, we are not depending on the favor of another person, living in a wheel chair, in a bed, we have a house and food! (S5, M, 65).

[...] the person has to be happy, value the things that God gives to us! [...] I have to be in my place, I am poor! Then I agree with everything that God gives us; I cannot complain about luck or being unhappy... (S1, F, 74).

[...] I have a good quality of life, but at the same time I do not, because I am in need of work, money, what to eat, but I cannot complain! (S3, M, 56);

The theme that represents the meaning of quality of life for the social group studied was - "being as happy as possible". This meaning of quality of life was built in the interrelation between the level of satisfaction and importance the dimensions related to having health, work and family mean in these people's lives. This perception denotes that the notions of well being or quality of life depend on the choices and considerations made, on the relative valuations and on the meanings attributed to the values faced.

This theme was identified from the acknowledgements of the contradictions that permeate life and the concepts the individuals elaborated intersubjetively in their sociocultural context. It was possible to understand that some people consider themselves satisfied with their quality of life when it results from the attribution of importance and priority in existing, considering health from the spiritual point of view, and becoming as family welcoming. Some said they are not satisfied with quality of life when they think of the aspects resulting from the prejudice of the dimension - "becoming" - related to the difficulty to return to work and, consequently, they face financial limitations and decreased power to control their choices and decisions, leading to dependence on the family.

\section{FINAL CONSIDERATIONS}

The meaning of quality of life for the group under study involves being as happy as possible and is based on having health, work and harmony in the family. These were considered dimensions for a "calm and happy" life.

The meaning of quality of life is subject to re-significations during life and is closely related with the socioeconomic and cultural context, influenced by beliefs, values, attitude, in view of the different phenomena experienced during life, including, in this case, the health-disease process.

Understanding the meaning of quality of life contributes to develop researchers and health professionals' abilities to evaluate, re-evaluate and elaborate individual and community health care programs that attend to these persons' or groups' needs and promote favorable conditions for the empowerment and active participation of individuals in their health care. This process will contribute for health professionals to rethink their practice and, then, search for more integrative health care models in which alterity, humanism and individuality are valued and guiding aspects of their actions.

\section{REFERENCES}

1. Lotufo PA. Epidemiologia das doenças isquêmicas do coração no Brasil. In: Lessa I. O adulto brasileiro e as doenças da modernidade: epidemiologia das doenças crônicas nãotransmissíveis. São Paulo (SP): Hucitec; 1998. p. 115-22. 2. Barnason S, Zimmerman L, Anderson A, Mohr-Burt S, Nieveen J. Functional status outcomes of patients with a coronary artery bypass graft over time. Heart Lung 2000 January-February; 20(1):33-46.
3. Dantas RAS, Motzer SA, Ciol MA. The relationship between quality of life, sense of coherence and self-esteem in persons after coronary artery bypass graft surgery. Int J Nurs Stud 2002 September; 39(7):745-55.

4. Roebuck A, Furze G, Thompson DR. Health-related quality of life after myocardial infarction: an interview study. J Adv Nurs 2001 June; 34(6):787-94.

5. Ross AC, Ostrow L. Subjectively perceived quality of life after coronary artery bypass surgery. Am J Crit Care 2001 January; 10(1):11-6. 
6. Spertus JA, Winder JA, Dewhurst TA, Deyo RA, Finn SD. Monitoring the quality of life in patients with coronary artery disease. Am J Cardiol 1994 December; 74(12):1240-4.

7. Padilla GV, Kagawa-Singer M. Quality of life and culture. In: King CR, Hinds PS. Quality of life from nursing and patient perspectives: theory, research, practice. Boston: Jones and Bartlett Publishers; 1998. p. 74-92.

8. Renwick R, Brown I, Nagler M. Quality of life in health promotion and rehabilitation: conceptual approaches, issues, and applications. London: Sage; 1996.

9. Renwick R. Quality of life: a guiding framework for practice with adults with developmental disabilities. In: Ross M, Bachner S. Adults with developmental disabilities. New York: Aota Press; 2004. p. 20-38.

10. Costa MCS. Intersubjetividade e historicidade: contribuições da moderna hermenêutica à pesquisa etnográfica. Rev Latino-am Enfermagem 2002 maio/junho; $10(3): 372-82$.

11. Geertz C. A interpretação das culturas. Rio de Janeiro (RJ): LTC - Livros Técnicos e Científicos; 1989.

12. Kleinman A. Patients and healers in the context of culture. Berkley: University of California; 1980.

13. Almeida N Filho, Andrade RFS. Holopatogênese: esboço de uma teoria geral de saúde - doença como base para a promoção da saúde. In: Czeresnia D, Freitas CM. Promoção de saúde: conceitos, reflexões, tendências. Rio de Janeiro (RJ): Fiocruz, 2003. p. 97-115.

14. Coelho MTAD, Almeida N Filho. Análise do conceito de saúde a partir da epistemologia de Canguilhem e Foucault. In: Goldenberg P, Marsiglia RMG, Gomes MHA, organizadoras. O clássico e o novo: tendências, objetos e abordagens em ciências sociais e saúde. Rio de Janeiro (RJ): Fiocruz; 2003. p.101-13.

15. Fleck, MP, Borges, ZN, Bolognesi, G, da Rocha NS. Desenvolvimento do WHOQOL, módulo espiritualidade, religiosidade e crenças pessoais. Rev Saude Publica 2003 agosto; 37(4):446-55.

16. Nucci NAG. Qualidade de vida e câncer: um estudo compreensivo. [dissertação]. Ribeirão Preto (SP): Faculdade de Filosofia, Letras e Ciências Humanas/USP; 2003.

17. Maruyama SAT. A experiência da colostomia por câncer como ruptura biográfica na visão dos portadores, familiares e profissionais de saúde: um estudo etnográfico. [dissertação]. Ribeirão Preto (SP): Escola de Enfermagem de Ribeirão Preto/ USP; 2004.

18. Glat R. O papel da família na integração do portador de deficiência. Rev Bras Educ Esp 1996 abril; 2(4):111-6. 